\section{Effect of Plant Age on Survival of Diamondback Moth on Two Cabbage Genotypes}

\author{
S.D. Eigenbrode and A.M. Shelton \\ Department of Entomology, New York State Agricultural Experiment \\ Station, Geneva, NY 14456
}

Additional index words. Brassica oleracea, Plutella xylostella
Knowledge of age-dependent expression of resistance is critical for evaluation of breeding lines and for effective use of resistant cultivars in pest management. Resistance to the Lepidoptera pest complex in some Brassica has been shown to increase with plant' age (Dickson and Eckenrode, 1980). Our studies of insect resistance now focus on the diamondback moth [Plutella xylostella (L.)], the most serious pest of cole crops worldwide (Talekar and Griggs, 1986). Resistance to this insect in glossy Brassica genotypes, descended from cauliflower $\mathrm{P} 1234599$, is due to reduced larval survival (Lin et al., 1983; Eigenbrode et al., 1990). The objective of this study was to measure survival of diamondback moth larvae throughout crop development in NY accession 2518, a glossy-leafed resistant inbred cabbage line, and the susceptible hybrid 'Round Up'.

Resistance was measured by inoculating the fourth expanded leaf of test plants with 100 to 200 diamondback moth eggs (depending on plant size) and determining percent of larvae surviving 8 to 10 days later (fourth instar (Eigenbrode et al., 1990). Two experimental designs produced plants for inoculation $14,28,42,56$, and 70 days after transplanting. In the first experiment (Single Cohort), 45 eight-week-old seedlings of each line were transplanted from Speedling-type flats into the field on 6 June 1988. Six to nine plants from each line were inoculated on 20 June, 5 and 18 July, and 1 and 15 Aug. In the second experiment (Single Inoculation), six to nine g-week-old seedlings from each line were transplanted on 6 and 20 June, 5 and 18 July, and 1 Aug. All plants in this design were inoculated on 15 Aug.

Received for publication 10 May 1989. We thank R. Burgess for technical assistance and M.H. of the manuscript. The cost of publishing this paper was defrayed in part by the payment of page charges. Under postal regulations, this paper therefore must be hereby marked advertisement solely to indicate this fact. Dickson and M.T. Vittum for reviewing early drafts
2518 plants may be due to the quality or size of the plants, or both. Transplanted seedlings, which have relatively hard leaves, may resist feeding until new growth occurs. Also, smaller plants may provide the larvae fewer refuges from rain, desiccation, and other environmental causes of mortality. As a result, diamondback moth larvae may survive poorly on plants of both genotypes soon after transplant, while later in crop development only the resistance mechanisms of the glossy plants continue to operate. Regardless of the mechanisms involved, our study shows that NY 2518 is highly resistant to diamondback moth, due to reduced larval survival, from 2 weeks after transplant. This result is consistent with Dickson and Eckenrode's (1980) report that a related glossy cabbage had consistently low injury from the Lepidoptera pest complex at 33 and 66 days after transplant. Our result suggests that cultivars resistant to diamondback moth from transplant to harvest can be derived from NY 2518 or related glossy lines.

\section{Literature Cited}

gle Inoculation experiment, the percentage of larvae surviving on 'Round Up' was lowest in the 14- and 28-day periods. In both experiments, larval survival on NY 2518 was consistently low, never higher than $10.3 \%$.

In the Single Inoculation experiment, relative resistance generally increased with plant age, although the effect was not significant. This pattern was mostly due to increased larval survival with increased plant maturity on 'Round Up'. In the Single Cohort experiment, environmental effects on larval survival in the different inoculations may have obscured plant age effects on relative resistance.

Resistance in younger 'Round Up' and NY
Table 1. Percentage of larvae surviving on cabbage cultivar Round Up and diamondback moth-resistant glossy-leafed cabbage NY 2518, and relative resistance of NY 2518 (survival on NY 2518 expressed as a percentage of that on 'Round Up') at five plant ages and two inoculation schemes. ${ }^{z}$

\begin{tabular}{|c|c|c|c|c|c|c|c|}
\hline \multirow[b]{2}{*}{ Entry } & \multicolumn{6}{|c|}{ Days after transplanting } & \multirow{2}{*}{$\begin{array}{l}P \text { value } \\
\text { for } F \text { test }\end{array}$} \\
\hline & 14 & 2 & 8 & 42 & 56 & 70 & \\
\hline & \multicolumn{7}{|c|}{ Larvae surviving (\%) } \\
\hline Single cohort & & & & & & & \\
\hline Round up & $4.8 \pm 1.3 c$ & $77.2 \pm$ & $16.1 \mathrm{a}$ & $54.7 \pm 14.7 \mathrm{a}$ & $22.4 \pm 2.7 \mathrm{~b}$ & $62.3 \pm 7.9 \mathrm{a}$ & 0.0001 \\
\hline NY 2518 & $0.2 \pm 0.2 b$ & $10.3 \pm$ & $3.7 \mathrm{a}$ & $0.0 \pm 0.0 \mathrm{~b}$ & $0.3 \pm 0.2 b$ & $7.9 \pm 1.7 \mathrm{a}$ & 0.0001 \\
\hline $\begin{array}{l}\text { Relative } \\
\text { resistance } \\
\text { Single inoculati }\end{array}$ & $4.7 \pm 3.1 \mathrm{~b}$ & $13.4 \pm$ & $4.8 \mathrm{a}$ & $0.0 \pm 0.0 \mathrm{~b}$ & $0.3 \pm 0.2 b$ & $12.6 \pm 2.8 \mathrm{a}$ & 0.001 \\
\hline $\begin{array}{l}\text { Single inoculati } \\
\text { Round Up }\end{array}$ & & & & & & & \\
\hline $\begin{array}{l}\text { Round Up } \\
\text { NY } 2518\end{array}$ & $\begin{aligned} 23.7 & \pm 4.4 \mathrm{~b} \\
5.0 & \pm 1.2 \mathrm{a}\end{aligned}$ & $\begin{aligned} 23.3 \pm \\
7.3 \pm\end{aligned}$ & $\begin{array}{l}9.2 \mathrm{~b} \\
3.0 \mathrm{a}\end{array}$ & $\begin{array}{r}62.8 \pm 9.8 \mathrm{a} \\
8.5 \pm 2.8 \mathrm{a}\end{array}$ & $\begin{aligned} 69.8 & \pm 9.1 \mathrm{a} \\
8.3 & \pm 2.0 \mathrm{a}\end{aligned}$ & $\begin{array}{r}62.3 \pm 7.9 \mathrm{a} \\
7.9 \pm 1.7 \mathrm{a}\end{array}$ & $\begin{array}{l}0.0001 \\
\text { NS }\end{array}$ \\
\hline $\begin{array}{l}\text { Relative } \\
\text { resistance }\end{array}$ & $21.8 \pm 5.1 \mathrm{a}$ & $31.0 \pm$ & $12.9 \mathrm{a}$ & $13.5 \pm 4.5 a$ & $13.9 \pm 3.3 \mathrm{a}$ & $12.6 \pm 2.8 \mathrm{a}$ & NS \\
\hline
\end{tabular}

'Comparisons, using Student's t test, between 'Round Up' and NY 2518 at each point after transplanting in each inoculation scheme were significant $(P \leq 0.001)$, except 28 days in the Single Inoculation $(P$ $=0.067)$. Means in each row with the same letter are not significantly different $(P \leq 0.05$, Fisher's protected LSD). NS = nonsignificant. 